\title{
NOTES
}

\section{CHILLED TO THE PILL: THE JAPANESE JUDICIARY'S COOL RECEPTION OF THE POISON PILL AND POTENTIAL REPERCUSSIONS}

Douglas G. Gruener ${ }^{*}$

\section{INTRODUCTION}

While the 1990s is frequently referred to as Japan's "lost decade" because of the nation's economic underperformance and weak structures for corporate governance, ${ }^{1}$ the past few years have shown a business environment that is in the midst of significant transition. Most importantly, Japan is experiencing a boom in mergers and acquisitions (M\&A), with the first half of 2005 alone accounting for an aggregate value of $\$ 108.9$ billion in Japanese M\&A transactions (greater than the $\$ 108.5$ billion of deal value accumulated in all of 2004). ${ }^{2}$ Among the major factors contributing to this trend are the improved cash positions of many companies, a record level of foreign share ownership that has helped strengthen shareholder activism, and, perhaps most significantly, the gradual unwinding of stable cross-shareholding relationships that were previously a staple of Japanese corporate strategy and stability. ${ }^{3}$

* J.D. University of Pittsburgh School of Law, May 2006.

1. See, e.g., JaPAN's Lost DeCAde: Policies for ECONOMic Revival 1 (Tim Callen \& Jonathan D. Ostry eds., 2003) (documenting that the average annual growth of real GDP in Japan was a mere one percent for much of the decade).

2. Japan External Trade Organization, Japan's M\&A Activity Continues to Grow (2005), http://www.jetro.org/content/264.

3. Robert Feldman, Japan Gets Ready to Surf a Wave of Mergers, Fin. Times, Nov. 3, 2004, at 17. 
The dissipation of cross-shareholdings is especially important because these arrangements, in which companies would agree with certain business partners or affiliated entities to purchase each other's shares under a mutual understanding that the shares would not be traded, were considered to be conclusive of the fact that in Japan "the stock market has not been a viable venue for contesting corporate control.", According to some estimates, there were times when up to 70 percent of outstanding Japanese corporate equity was held in these relationships, ${ }^{5}$ making it mathematically impossible for change-of-control transactions to occur through the market. However, the composition of the market is much different today, and a recent report by the Nissei Research Institute estimates that cross-shareholdings among corporations and banks fell on a value basis from 18.5 percent in 1987 to 7.6 percent in $2003 .^{6}$

Since cross-shareholdings were an integral part of the keiretsu ${ }^{7}$ relationships that enabled Japan to become an economic powerhouse in the 20 th century, ${ }^{8}$ it is not surprising that their extinguishment has been slow and not entirely voluntary. Rather, stable shareholdings have dissipated "mainly because the poor performance of the Japanese stock market in the past ten years made shareholding relatively costly." In addition, changes were made to Japanese accounting principles that require companies to start recognizing the fair value of their equity holdings in their financial statements and impairment losses for certain deflated securities. ${ }^{10}$

4. Edward J. Lincoln, Arthritic Japan: The Slow Pace of Economic Reform 30 (2001).

5. Id.

6. Japan External Trade Organization, supra note 2. Although it will not be discussed further in this Note, it must be noted here that recent scholarship has called into question the veracity of data regarding cross-shareholdings in Japan. See Yoshiro Miwa \& J. Mark Ramseyer, The Myth of the Main Bank: Japan and Comparative Corporate Governance, 27 LAW \& Soc. INQUIR Y 401, 414 (2002) (stating that "[k]eiretsu 'cross-shareholdings' are not now unwinding, for there were no arrangements to unwind.").

7. Keiretsu refers to Japan's famed industrial combines, within which affiliated companies benefited from the financial and managerial support of a main bank, and were (and perhaps still are) able to maintain low costs through the use of long-term suppliers who belong to the same group. See KENICHI Miyashita \& David Russell, Keiretsu: Inside the Hidden Japanese Conglomerates 49-53, 118-21 (1996).

8. For an account of how cross-shareholdings contributed to the strength of keiretsu, see id. at 66-70.

9. Hideki Kanda, Does Corporate Law Really Matter in Hostile Takeovers?: Commenting on Professor Gilson and Chancellor Chandler, 2004 Colum. Bus. L. Rev. 67, 70.

10. Katsumasa Suzuki, Future Prospects of Takeovers in Japan Analyzed from the View of Shareownership Structures and Laws in Comparison with the United States and the European Union, 42 Colum. J. Transnat’L L. 777, 816-18 (2004). 
Under these circumstances, Japan is experiencing a market for corporate control for the first time. ${ }^{11}$ Since the emergence of hostile takeovers in Japan is essentially an outgrowth of the extended economic malaise that led to incremental changes in the fundamental capital structures and business methods of Japanese companies, it was not unforeseeable as of a few years ago. Thus, in 2002 the Japanese Commercial Code was amended to make technically feasible another new feature of the corporate environment ${ }^{12}$ - the poison pill. ${ }^{13}$ The invention of famed takeover lawyer Martin Lipton, the pill is clearly the most popular takeover defense in the United States, with recent estimates that it is in effect at over 2,300 companies. ${ }^{14}$ The poison pill is a particularly desirable defensive measure because its adoption involves no significant outlay of cash or fundamental change to the capital structure of the corporation. In addition, rather than acting as a preclusive defense against takeovers, the pill has been shown to provide target directors with valuable time to evaluate and negotiate a tender offer and ultimately secure a high premium in the event of a sale of control. ${ }^{15}$

While early news reports on the introduction of poison pills to Japan indicated that the devices might be widely adopted as a replacement defense for cross-shareholdings, the preliminary evidence points to a more limited and gradual implementation. At the June 2005 corporate shareholders' meetings in Japan, eight companies successfully received shareholder approval of their poison pill plans. ${ }^{16}$ However, three others had proposals to increase

11. See Curtis J. Milhaupt, In the Shadow of Delaware? The Rise of Hostile Takeovers in Japan, 105 Colum. L. Rev. 2171 (2005).

12. Seе Зно̄Hō [Commercial Code], arts. 280-19 to 280-39, available at http://www1.oecd.org/ daf/asiacom/pdf/japan_commercial_code.pdf (in English) (authorizing the issuance of warrants without shareholder approval at a price determined by the board).

13. Formally known as a "shareholder rights plan," the typical modern poison pill in the United States (known as a "flip-in" type) is a right issued as a pro rata distribution that, upon a "triggering event" of one individual or entity acquiring a certain percentage of the company's shares, allows all common shareholders except for the hostile acquirer to convert their rights and acquire more of the corporation's stock at a significant discount from the market price during a limited time period. This issuance of large amounts of new stock severely dilutes the hostile bidder's stake in the company and thwarts the takeover attempt. "Flip-over" poison pills, in which the shareholders of an acquired company can exercise the right to purchase shares of the acquiring company at a discounted price upon a triggering event, are also common in the United States. For examples of both, see Moran v. Household Int'1, Inc., 500 A.2d 1346 (Del. 1985).

14. Patricia A. Vlahakis, Takeover Law and Practice 2005, at 1329 (PLI Corp. Law \& Practice, Course Handbook Series No. 6063, 2005).

15. Id. at 1328-29.

16. Kotaro Tsuru, How to Cope with the Threat of Hostile Takeovers: Japanese Corporate Governance at a Crossroads (2005), http://www.rieti.go.jp/en/papers/contribution/tsuru/02.html. 
authorized capital stock rejected by shareholders, ${ }^{17}$ which is significant because "the number of shares issuable upon exercise of stock acquisition rights may not exceed the number of authorized shares (which may not exceed four times as many as the total number of issued shares)." ${ }^{.18}$ More importantly for those analyzing the pill in Japan from a legal perspective, two takeover defenses were recently challenged before the Tokyo District Court and were invalidated in both cases. ${ }^{19}$ Thus, shareholders and courts in Japan are not embracing the poison pill warmly as of yet, and its prospects for becoming widespread in the immediate future are not especially promising.

To some commentators, this treatment of the poison pill in Japan may be considered laudable, as it has been convincingly argued that hostile takeovers will play an important role in efficiently reallocating assets in the Japanese economy. ${ }^{20}$ However, this Note explores the possibility that this cool reception of the pill may be relatively short-lived, and even harmful, in Japan. Part I of this Note lays out the pieces of Japan's current legal approach to poison pill issuances, relying on government guidelines and the prominent decisions in the Livedoor and Nireco cases. Part II uses those sources to attempt to formulate the overall direction of the doctrine and assess what features a poison pill likely must possess to be successfully adopted. I argue that although the Japanese doctrine is in alignment with Delaware takeover jurisprudence on several counts, Japan has moved Delaware's standard ex post analysis of takeover defenses to an ex ante position and, in doing so, has created a standard that is inherently difficult to overcome. In addition, the Japanese judiciary has strongly implied that in order for Japanese directors to withstand a challenge to the validity of a poison pill, they must relinquish all decision-making authority over whether a pill should be redeemed. For these reasons, I argue that many companies in Japan will either decline to include the poison pill as a defense mechanism or have their pills overturned by shareholder challenge.

17. See id. (noting that the three companies were Tokyo Electron Ltd., Yokogawa Electric Corp., and Fanuc Ltd.).

18. Suzuki, supra note 10 , at $800-01$.

19. See Raibudoa K.K. v. Nippon Hoso K.K. (Tokyo D. Ct., Mar. 11, 2005), http:// courtdomino2.courts.go.jp/Kshanrei.nsf/webview/39474D7BE44D11CC49256FCF0028876A/ ?OpenDocument (in Japanese); SFP Value Realization Fund Ltd. v. Nireco K.K. (Tokyo D. Ct., June 1, 2005), http://courtdomino2.courts.go.jp/kshanrei.nsf/webview/88299A542BDC7FA649257015000CEE97/ ?OpenDocument (in Japanese). Both cases resulted in provisional orders enjoining the issuance of warrants.

20. See Ronald J. Gilson, The Poison Pill in Japan: The Missing Infrastructure, 2004 CoLum. Bus. L. REv. 21, 28-29. 
Part III argues that in consideration of the significantly improved environment for shareholder activism in Japan, these judicial limitations on the pill may be unnecessary. I explore potential effects of the current doctrine, including a possible legislative intervention that would effectively overrule the judiciary's decisions by making the poison pill or other defenses easier to adopt. If such legislation appears, it can only be hoped that it does not go too far in providing companies with preclusive tools for defense. Until or unless there is a legislative intervention, I also argue that current economic conditions mean there is a possibility that some companies will return to cross-shareholding as a takeover defense upon realizing the various difficulties involved in adopting a poison pill. Since poison pills have the potential to allow target directors to secure high premiums on behalf of shareholders and do not involve the fundamental capital structure changes that are necessary for cross-shareholding, this would be a regrettable development. This Note concludes that in order to avoid scenarios where Japanese companies have an incentive to revert to cross-shareholding and to make a potentially imbalanced legislative intervention less likely to occur, the Japanese judiciary should reconsider its current doctrinal direction to make poison pills easier to adopt in the face of shareholder challenges.

\section{Tools for Evaluating the Legality of Poison Pills in Japan}

\section{A. Government Guidelines Regarding Takeover Defenses}

In May 2005, the Ministry of Economy, Trade, and Industry (METI) and the Ministry of Justice (MOJ) jointly issued guidelines regarding takeover defenses "with the goal of preventing excessive defensive measures, enhancing the reasonableness of takeover defense measures and thereby promoting the establishment of fair rules governing corporate takeovers in the business community" 21 (hereinafter referred to as "Ministry Guidelines" or "Guidelines"). While the Ministry Guidelines are not legally binding, ${ }^{22}$ their

21. Ministry of Econ. Trade \& Indus. \& Ministry of Justice, Guidelines Regarding Takeover Defense for the Purposes of Protection and Enhancement of Corporate Value and SHAREHOLDERs' COMMON INTERESTS (2005), http://www.meti.go.jp/policy/economic_oganization/ pdf/shishin_hontai.pdf [hereinafter METI \& MOJ]. These Guidelines are at least in part based on the findings of a Corporate Value Study Group (CVSG) chaired by Professor Hideki Kanda of Tokyo University. For a summary report of CVSG's findings, see Corporate VALUe Study Group, Ministry of Econ. Trade \& Indus., Summary Outline of Discussion Points (2005), http://www.meti.go.jp/ english/information/downloadfiles/Corporate $\% 20$ Value.pdf.

22. METI \& MOJ, supra note 21 , at 3. 
message clearly impacted (or alternatively, was impacted by) the court decisions discussed later in this Note, and thus the Guidelines should not be taken lightly. ${ }^{23}$ Judicial reference to the Guidelines is perhaps inevitable, as other sources of guidance regarding the legal standards for takeover defenses remain sparse in Japan. ${ }^{24}$

The Ministry Guidelines established three broad principles for the development of takeover defenses in Japan: (1) the use of takeover defenses should be undertaken with the goal of protecting and enhancing corporate value and shareholders' common interests; (2) when defenses are adopted, their purpose and terms should be disclosed and should reflect the will of shareholders; and (3) the takeover defense measures in response to a possible takeover threat must be necessary and reasonable in relation to the threat posed. ${ }^{25}$ The Guidelines explain each of these principles in some detail, but only the central highlights will be covered for the purposes of this Note.

For the first principle, the Guidelines list several situations in which the adoption of defensive measures would clearly be undertaken for the protection of shareholders. These situations include takeover threats that would damage shareholders' interests because of the bidder's intentions (such as where the bidder is a greenmailer or intends to sell off the company's assets), coercive two-tiered takeovers, or simply where there is not adequate time to fully consider a bidder's offer or explore the possibility of superior alternatives. ${ }^{26}$

23. In this regard, it should also be noted that the Guidelines are expected to influence potential regulations to be issued by the Tokyo Stock Exchange (TSE). The TSE released voluntary guidelines on defensive measures on April 21, 2005. See Toкyo Stock Exсh., Tekitaiteki baishuu boueisaku no DOUNYUU NI SAISHITE NO TOUSHISHA HOGOJOU NO RYUUI JIKOU NI TSUITE [Considerations for the Protection of Investors in Adopting Hostile Takeover Defense Measures] (2005), http://www.tse.or.jp/ news/200504/050421_a.pdf (in Japanese).

24. The Commercial Code itself contains very little substantive guidance, but the following provisions are relevant: Article 280-22 requires approval of two-thirds or more shareholders for an issuance of stock acquisition rights that is "especially favorable," and Article 280-10 declares that shareholders may demand that an issuance of shares be suspended if it is conducted in a "significantly unfair manner." See SнōHō, supra note 12, at arts. 280-22 and 280-10; Satoshi Kawai, Poison Pill in Japan, 2004 Colum. Bus. L. REv. 11 n.4. Court precedents on takeover defenses are also sparse, but at least one case is illuminating regarding a possible "primary purpose" rule that applies to Article 280-10. Shuwa K.K. v. K.K. Chujitsuya, 1317 HanR EI JiHō 28 (Tokyo D. Ct., July 25, 1989), translated in Law And InVestment IN JAPAN 550-53 (Yukio Yanagida et al. eds., 2d ed. 2000) (holding that Chujitsuya's issuance of new shares to a white knight in order to dilute the holdings of Shuwa was illegal because it was not approved by a special resolution of a general shareholders' meeting and it was unfair under Article 280-10 of the Commercial Code as a result of its primary purpose being to dilute Shuwa's holdings rather than to raise capital).

25. METI \& MOJ, supra note 21, at 3-4.

26. Id. at $4-5$. 
Under the second principle, the Guidelines heavily imply that the easiest way for directors to demonstrate that a defensive measure reflects the will of shareholders is to gain shareholders' approval at a general meeting following a full disclosure of the measure's purpose, term, and effects. "When stock acquisition rights, etc. are issued as a takeover defense measure based on approval at the general meeting of stockholders ... there is a high probability that such measures will be considered in compliance with the three principles of the Guidelines, and thus constitute a fair issuance." ${ }^{27}$ Conversely, where the takeover defense is based on a resolution of the board of directors without receiving shareholder approval, satisfaction of the second principle makes it "necessary to provide a mechanism to allow shareholders to cause the termination of such rights based on the general consensus of the shareholders. ${ }^{28}$

To meet the third principle of necessity and reasonableness, the Guidelines state that due consideration should be given to principles of shareholder equality, protection of property rights, and the prevention of the abuse of defensive measures to achieve management entrenchment. ${ }^{29}$ The Guidelines again indicate that it is desirable if the shareholders have a mechanism to remove the defensive measures ${ }^{30}$ and also state that defensive measures must not create financial losses for the shareholders (other than the acquiring entity). ${ }^{31}$ Finally, the Guidelines suggest the establishment of objective criteria that would cause a defensive measure to terminate automatically after a period of evaluation and negotiation regarding a qualifying offer, ${ }^{32}$ and additionally endorse the use of "independent outsiders" to evaluate takeover offers. ${ }^{33}$

27. Id. at 9. On a related note, the Guidelines state that "reasonableness is increased by establishing measures to ensure regular opportunities to verify the shareholders' will as a whole, for example, a [sunset] provision to require the periodic approval of the [defensive measure] at general shareholders meetings after the issuance." Id. at 9-10.

28. Id. at 11 .

29. Id. at 7.

30. Id. at 9 .

31. Id. at 11 .

32. Id. at 13. This is known as the "chewable pill." See Corporate Value Study Group, supra note 21 , at 9 .

33. METI \& MOJ, supra note 21, at 14. 


\section{B. The Case of Livedoor}

In February 2005, Takafumi Horie, the thirty-two-year-old founder and president of the Internet company Livedoor, sparked the biggest Japanese business story of the year by announcing that his company had acquired 35 percent of the radio company Nippon Broadcasting System, Inc. (NBS) in after-hours stock trading. ${ }^{34}$ Livedoor was able to consummate the large purchase by utilizing a rather gaping loophole in Japan's Securities and Exchange Act, which only required a takeover bid for one-third or more of a company's shares to be publicly disclosed and open to all shareholders if it were attempted outside the stock exchange. ${ }^{35}$ Horie openly communicated that the true intention of the purchase was to gain control of Fuji Television Network, Inc. (Fuji TV), a leading broadcast company in which NBS owned a 22.5 percent stake. ${ }^{36}$ At the time of Livedoor's purchase, Fuji TV had already made a premium tender offer for all shares of NBS in an effort to rectify their distorted cross-shareholding relationship within the Fuji Sankei media group. ${ }^{37}$ The distortion stemmed from the fact that despite Fuji TV's $\$ 5.55$ billion market capitalization being more than double that of NBS, NBS held a 22.5 percent stake in Fuji TV while Fuji TV only held 12.4 percent of the stock of NBS. ${ }^{38}$

With the stage set for a battle between Horie, "a young college dropout in T-shirt and jeans," and the "starched-shirted sixty-somethings" managing the Fuji Sankei group entities, Livedoor's takeover attempt captured unprecedented media attention in Japan. ${ }^{39}$ While Livedoor continued to purchase NBS shares in the weeks following the initial announcement, NBS quickly moved to block Livedoor's quest for total control by issuing warrants (shin kabu yoyaku ken) to Fuji TV exercisable into 47.2 million shares of NBS stock, a move authorized by the 2002 amendments to the Commercial Code. ${ }^{40}$ Soon thereafter, Livedoor applied for an injunction against the issuance of warrants in the Tokyo District Court, which ruled in Livedoor's favor on March 11, 2005 and granted the injunction. ${ }^{41}$ The decision was

26.

34. Michiyo Nakamoto, Tokyo Might Tighten Stock Trading Rules, Fin. Times, Feb. 16, 2005, at

35. Id.

36. $I d$.

37. Michiyo Nakamoto, Shareholders Achieve a Rare Victory, Fin. TIMES, Jan. 20, 2005, at 29

38. Michiyo Nakamoto, Bids for NBS Shake up Corporate Japan, Fin. TIMEs, Feb. 17, 2005, at 25.

39. Milhaupt, supra note 11 , at 2181 .

40. Id. at 2179 .

41. Michiyo Nakamoto, Livedoor Wins Key Fight in NBS Campaign, Fin. Times, Mar. 12, 2005, 
affirmed by the Tokyo High Court on March 23, 2005. ${ }^{42}$ This result was perhaps unsurprising under the precedent of Shuwa $v$. Chujitsuya, ${ }^{43}$ as it was clear that there was no capital-raising justification for the warrants, and the exercise of the warrants would have increased NBS's share capital by 140 percent ${ }^{44}$ and severely diluted the ownership stake of all shareholders other than Fuji TV (not just the hostile bidder). In the sense that the warrants were not issued on a pro rata basis to all shareholders other than the hostile bidder, Livedoor is not a true case of the poison pill.

Nevertheless, the precedent is significant to the analysis of poison pills because in its opinion, the High Court chose to enumerate situations in which the issuance of dilutive warrants in the midst of a hostile bid would be justified: (1) cases of greenmail in which the bidder intends to make the target company repurchase the shares at a premium, (2) "scorched earth" situations where the bidder intends to transfer the company's intellectual property to the bidder or its affiliates, (3) where the bidder's intention is to acquire control in order to use the target's assets to secure or pay the bidder's debts, and (4) situations where the bidder intends to sell off assets not related to the core business in order to pay a one-time dividend. ${ }^{45}$ The common theme of the list is the likelihood of exploitation by the bidder and consequent detriment to shareholders.

The Livedoor saga is also a significant point of analysis because the defense that NBS and Fuji TV attempted to raise was not limited to the issuance of warrants. Following the District Court's injunction of the warrants, NBS threatened to sell its 56 percent stake in Pony Canyon (a highly successful music and video publishing company) if the Livedoor bid looked likely to succeed ${ }^{46}$ - a classic crown jewel defense. Around the same time, Fuji TV announced that it would double its dividend payouts as compared with 2004, which was seen as a maneuver to boost its share price and make it more difficult for Livedoor to try a full takeover. ${ }^{47}$ Soon thereafter, Fuji TV

at 8 .

42. Michiyo Nakamoto, Ruling Takes Livedoor Closer, Fin. Times, Mar. 24, 2005, at 26 [hereinafter Nakamoto, Ruling Takes Livedoor Closer].

43. See supra note 24 for a description of this case.

44. Michiyo Nakamoto, Changing Channels: A Bid Is Bringing Public Scrutiny to Japan's Boardrooms, Fin. Times, Mar. 22, 2005, at 15 [hereinafter Nakamoto, Changing Channels].

45. Milhaupt, supra note 11, at 2193-94. This same list was approved by METI and MOJ when they issued the Ministry Guidelines. See METI \& MOJ, supra note 21, at 16.

46. Michiyo Nakamoto, NBS Threatens Sale to Thwart Livedoor, Fin. Times, Mar. 15, 2005, at 29.

47. Michiyo Nakamoto, Fuji TV Doubles its Dividend to Try to Fend off Livedoor, Fin. Times, Mar. 16, 2005, at 15. 
filed an application to issue up to $\$ 474$ million in new shares in hopes of making a takeover even more difficult. ${ }^{48}$ Finally, after the District Court's decision was affirmed and it became apparent that the issuance of share warrants would not be possible, Softbank Investment (SBI) emerged as a white knight and "borrowed" a 13.88 percent stake in Fuji TV from NBS, replacing NBS as Fuji TV's largest shareholder. ${ }^{49}$ As a result, Livedoor's gain of control over NBS no longer meant that the corollary of control over Fuji TV would exist, and Horie had little choice but to seek a truce with Fuji TV. As part of the agreement the parties reached, Livedoor sold its entire stake in NBS to Fuji TV at a slight profit, and in return Fuji TV invested around $\$ 440$ million in Livedoor and agreed to establish a business alliance. ${ }^{50}$ If nothing else, this story demonstrates that despite Japanese companies' lack of direct experience with hostile takeovers, they are certainly not unskilled at creating and implementing a variety of strategic defenses.

\section{The Case of Nireco}

Japan's first true poison pill case arose earlier this year when SFP Value Realization Fund Ltd. of the Cayman Islands challenged the shareholder rights plan of Nireco, a manufacturer of high-tech measuring devices and controllers. Nireco's "security plan," announced at a board meeting on March 14, 2005, provided that all registered shareholders as of March 31, 2005 would receive two equity warrants for each share they owned (for free); each warrant in turn would provide the right to buy one new share of stock for one yen upon the occurrence of a triggering event. ${ }^{51}$ The triggering event was defined as the acquisition of 20 percent or more of the company by any single entity, and the period for exercise of the warrants was determined to be from June 16, 2005 to June $16,2008 .^{52}$ The plan declared that the warrants would only be exercisable by shareholders who received them directly from the company as a result of being a registered shareholder on March 31, 2005, and that the warrants were not transferable thereafter. ${ }^{53}$ At the time of the announcement,

\footnotetext{
48. Nakamoto, Ruling Takes Livedoor Closer, supra note 42.

49. David Pilling, White Knight New Villain of Fuji TV Saga, Fin. Times, Mar. 28, 2005, at 21. at 28 .

50. Michiyo Nakamoto, Halfway House Between Old and New Japan, Fin. Times, Apr. 19, 2005 ,

51. SFP Value Realization Fund Ltd. v. Nireco K.K. (Tokyo D. Ct., June 1, 2005), at 2-3, http://courtdomino2.courts.go.jp/kshanrei.nsf/webview/88299A542BDC7FA649257015000CEE97/?O penDocument (in Japanese).

52. Id. at 3 .

53. Id. at 4 .
} 
SFP was the owner of 2.85 percent of Nireco's stock. ${ }^{54}$ Nireco's directors did not pursue shareholder approval for the plan, but listed the following justifications for the poison pill: stable shareholdings had declined such that thirteen percent of the company was being held by pure investment funds, the company's price-to-book-value ratio was well under one, the company possessed high cash assets, and in 2004 the company had been listed by a prominent economics newspaper as being the seventy-first most likely company in Japan to be acquired by a tender offer. ${ }^{55}$ Nireco declared that the purpose of the plan was to prevent a harmful takeover in advance and to maximize the company's value. ${ }^{56}$

At the time of the plan's adoption, the directors also had defined the conditions for redemption. The decision about whether to redeem the pill would focus on the maximization of company value, the effect of the takeover bid on minority shareholders, and the opinion of a special three-member committee that was to be fully respected. ${ }^{57}$ Perhaps sensing that the final aspect could be significant to the court's decision, the board actually changed the composition of the special committee after SFP had filed its lawsuit to achieve a greater degree of independence. While the original committee consisted of a company executive, a lawyer, and a professor, as of May 20, 2005 , the committee was changed to two lawyers and a professor, and its opinion would be fully respected and followed unless there was an exceptional case where it became clear that the takeover would damage the company's value. ${ }^{58}$ In addition to this change, Nireco's board clarified the methods and timing of its disclosure that a triggering event had occurred and declared that any further changes to the rights plan would require unanimous approval of the special committee and immediate disclosure. ${ }^{59}$ Finally, Nireco's May 20, 2005 alterations to its rights plan included a direct reference to the Livedoor decision. Specifically, the board announced that a decision not to redeem the poison pill would generally be found in the four situations listed by the Livedoor court $^{60}$ and in other cases where the directors find a risk of damage

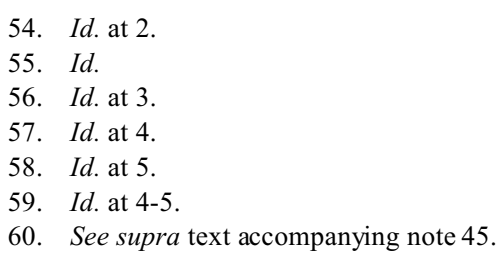


to company stakeholders. ${ }^{61}$ In the final scenario, the board would bear the burden of proving the risk of damage. ${ }^{62}$

Despite these improvements to the rights plan, on June 1 the Tokyo District Court granted the injunction that SFP was seeking, and the decision was affirmed by the Tokyo High Court on June $15 .{ }^{63}$ Although SFP argued that the rights plan violated several sections of the Commercial Code, the District Court only agreed that there had been a violation of the Commercial Code's prohibition on "significantly unfair" issuances. ${ }^{64}$ The District Court pointed out a rather obvious defect of the Nireco poison pill - because only the registered shareholders as of March 31, 2005 received the warrants, and because those warrants were declared nontransferable by the board ${ }^{65}$ anyone investing after the point in time at which it was possible to appear on the March 31 register and thereby receive the warrants (thought to be a March 27 purchase date) would face a severe risk of dilution from the possibility of the pill being activated and not redeemed. ${ }^{66}$ As a result of these circumstances, rational investors would place a lower value on Nireco shares starting on March 28, and a depression of the stock price to the detriment of all shareholders would be expected. ${ }^{67}$

While the decision to suspend Nireco's poison pill could surely have been based on this flaw alone, the District Court went further by stating that "in the

61. SFP Value Realization Fund Ltd. v. Nireco K.K. (Tokyo D. Ct., June 1, 2005), at 5, http:// courtdomino2.courts.go.jp/kshanrei.nsf/webview/88299A542BDC7FA649257015000CEE97/ ?OpenDocument (in Japanese).

62. $I d$.

63. See SFP Value Realization Fund Ltd. v. Nireco K.K. (Tokyo High Ct., June 15, 2005), http:// courtdomino2.courts.go.jp/kshanrei.nsf/webview/467B8F7BF9AD58B949257022002D65 AB/ ?OpenDocument (in Japanese).

64. SFP Value Realization Fund Ltd. v. Nireco K.K. (Tokyo D. Ct., June 1, 2005), at 15, available at http://courtdomino2.courts.go.jp/kshanrei.nsf/webview/88299A542BDC7FA649257015000CEE97/ ?OpenDocument (in Japanese).

65. Even without this imposition on the warrants by the board, issues of transferability are problematic in Japan because

$[\mathrm{u}] \mathrm{nder}$ the Japanese Commercial Code, stock and options to issue stock ... are different securities. Even if stock and stock acquisition rights are issued to the same person, it is difficult to ensure they are automatically distributed together because such person may sell or dispose of the stock and stock acquisition rights separately.

Kawai, supra note 24, at 13. This problem does not exist in Delaware, where poison pills attach automatically to all outstanding shares. See Leonard Loventhal Account v. Hilton Hotels Corp., No. Civ.A.17803, 2000 WL 1528909 (Del. Ch. Oct. 10, 2000).

66. SFP Value Realization Fund Ltd. v. Nireco K.K. (Tokyo D. Ct., June 1, 2005), at 6, available at http://courtdomino2.courts.go.jp/kshanrei.nsf/webview/88299A542BDC7FA649257015000CEE97/ ?OpenDocument (in Japanese).

67. Id. at 7 . 
adoption of a defensive measure in advance, such as the stock acquisition rights in [Nireco's] case, it is a general rule that it should be carried out based on the will of a general shareholders' meeting. ..." ${ }^{68}$ However, in recognition of the fact that, in the period between shareholders' meetings, it is possible for a takeover threat to appear that would cause incurable damage to the target company, the District Court recognized that directors can adopt advance takeover defenses without shareholder approval if their plans consider three conditions. ${ }^{69}$

First, there should be a mechanism to reflect the shareholders' opinion, such as giving shareholders the authority to decide whether or not to redeem a poison pill based on their own judgment. ${ }^{70}$ Second, there should be a structure to prevent the board of directors from making an arbitrary decision not to redeem a poison pill. ${ }^{71}$ To ensure that decisions against redemption only occur in situations where the hostile bidder would cause incurable damage to the company, there might be objective conditions set regarding the redemption decision or independent outsiders might be given the authority to decide. $^{72}$ Third, the adoption of a poison pill should not cause unexpected damage to the shareholders unrelated to the takeover. ${ }^{73}$

Despite the lack of necessity to the actual holding of the case, the District Court explained in dicta its reasoning for why Nireco's rights plan did not meet any of these conditions. Regarding the first condition, although the District Court recognized the possibility of a proxy contest in the future to replace the board and reflect the shareholders' desire to redeem the pill, the fact that no election was scheduled for the June 2005 shareholders meeting was considered significant. ${ }^{74}$ In addition, the planned agenda for this meeting did not include discussion of how the shareholders' opinion might be reflected in the redemption decision. ${ }^{75}$

68. Id. at 10 (translation by the author).

69. Id. at 10. Readers of this Note may recognize the somewhat contradictory message of this section of the opinion. While the court talks of the possibility of directors adopting a pill "in advance" (presumed to mean during "peacetime," when there is no specific cognizable threat), the situation cited as an example of when this is possible implies that it can only be done to ward off a threat of incurable damage. While the District Court's actual intent is unclear, one could interpret this section to mean that companies have little or no freedom to adopt a pill when their identifiable objective is to utilize its power to assist in the evaluation and negotiation of a future tender offer.

70. Id. at 11 .

71. Id.

72. $I d$.

73. $I d$.

74. Id.

75. $I d$. 
With regard to the second condition, the District Court held that Nireco's plan was not adequate despite the board of directors' aforementioned concession to five particular situations in which no redemption of the pill would be offered and its agreement that the guidelines would not be changed without unanimous approval of the special committee. The District Court made its decision regarding this condition on two bases: (1) the fifth listed situation (the only one not endorsed by the Livedoor opinion), in which the board could elect not to redeem a pill based on damage to the company's stakeholders, was considered to be too broad and unclear to prevent an arbitrary decision, and (2) for any redemption decision, although the board agreed to "fully respect" the opinion expressed by the special committee, the board reserved the right to make a decision contrary to the committee if it considered there to be danger to corporate value. ${ }^{76}$ Thus, by not completely relinquishing its authority over the redemption decision, the Nireco board failed the second condition of the District Court. This was in spite of the fact that the board had agreed to assume the burden of proof in cases where it claimed that a particular takeover offer would damage the company's stakeholders contrary to the opinion of the special committee.

For the third condition, the court's analysis was rather easy because the structure of Nireco's share warrants as only being issued to registered shareholders as of a particular date and the prohibition on the transfer of those warrants after their issuance had the obvious effect of making Nireco stock less attractive to investors. ${ }^{77}$ This structure created severe risks because the acquisition rights could not be purchased along with the stock and, as a result, even shareholders who received the warrants would face selling their shares at a depressed price. ${ }^{78}$ Thus, the risk of damage was obvious in the Nireco decision.

Near the end of its opinion, the District Court mentioned that Nireco might have reached its purpose in using this defensive measure if the first or third condition had been met. ${ }^{79}$ This comment somewhat skews the analysis appearing earlier in the opinion and implies that the three conditions are not a conjunctive test for the future, but rather are guidelines to be considered and satisfied if a poison pill issuance is to be upheld as legal. Nevertheless, the list of conditions remains a valuable initial precedent for Japan because where

\footnotetext{
76. Id. at 12 .

77. Id. at $13-14$

78. Id. at 14 .

79. Id. at 15 .
} 
any one of the three conditions is not met, it becomes likely that the takeover defense in question will be invalidated upon challenge.

\section{Assessment and Analysis of the Japanese Doctrine}

As it currently stands, the Japanese doctrinal direction for evaluating poison pills might be divided into three areas. (For the purpose of this assessment, the Ministry Guidelines are also considered despite being nonbinding.) First, it is evident that a target board's freedom in choosing to adopt a poison pill is dependent on the nature of the threat being posed to the company. In the event that a bidder appears who is likely to commit greenmail or other abusive strategies that would damage the target's shareholders, the Ministry Guidelines and Livedoor decision indicate that a board would be justified in taking a defensive measure even if it were dilutive to current shareholders. ${ }^{80}$ While the crucial question at the opposite end of the spectrum remains unanswered, namely what freedom the target board enjoys during a time with no specific cognizable threat, it seems unlikely that Japan is willing to provide directors with great leeway in adopting pills during "peacetime." This prediction is an extrapolation of the Livedoor decision, where despite Livedoor's unsolicited (and in the view of some, underhanded $^{81}$ ) acquisition of NBS shares, the court gave little consideration to the possibility that NBS's board had accurately perceived a threat to shareholder value. Rather, in part because there was no specific reason to anticipate that Livedoor held abusive intentions for its acquisition of NBS, the judiciary struck down NBS's defensive measure. In addition, despite Nireco's multiple arguments for why it was in danger of being a takeover target and needed an advance defensive measure, the opinion in Nireco gives the sense that the Tokyo District Court will not be persuaded by arguments regarding undervaluation and high cash assets. Furthermore, although the Nireco decision purportedly left open the possibility of directors adopting advance defenses, the District Court's opinion is somewhat contradictory by referring to a threat of incurable damage within the same discussion. ${ }^{82}$ Thus, when a

80. See METI \& MOJ, supra note 21, at 4-5; Milhaupt, supra note 11, at 2193-94.

81. During a discussion of the Livedoor saga on a popular Japanese television show, one guest used a racial epithet to describe president Takafumi Horie's business practices. See David Pilling \& Michiyo Nakamoto, Japan's Old Guard Gang up to Fight Young Pretender, Fin. Times, Feb. 28, 2005, at 18. A former bureaucrat described Horie as a modern-day greenmailer, stating " $\mathrm{h}] \mathrm{e}$ is in it for the money." Nakamoto, Changing Channels, supra note 44.

82. See supra note 69 and accompanying text. 
company adopts a defensive measure during "peacetime" and the measure is challenged, it seems very likely that the absence of a specific cognizable threat would weigh towards the measure being struck down by the judiciary. In this way, the current doctrine may develop such that peacetime pills rarely survive a challenge by shareholders.

Second, the pill needs to be structured so that it is likely to benefit shareholders. As the Nireco decision made apparent, when the structure of a pill makes it likely that share prices will be depressed and shareholder value will be harmed, there is very little question that a challenge to the pill will be successful. Thus, directors must take care to assure that the only party harmed by a poison pill is the hostile bidder to whom the defense is directed. To improve the likelihood that a pill will benefit shareholders, directors might also fully entrust shareholders with the decision of whether to redeem a pill after a tender offer has been announced. In this way, shareholders retain the ultimate decision of to whom and at what price they sell their shares. In addition, directors can consider making their pills "chewable" such that if a particular offer meets predetermined objective criteria, the pill terminates automatically.

Finally, the poison pill must possess characteristics that make it unlikely that it can be used simply for management entrenchment. This criterion can most directly be met by the board giving authority over the redemption decision to a committee of independent outsiders. As the Nireco decision strongly implies, it is probably necessary for the directors to provide the independent committee with complete authority over the decision because any retention of decision-making power by the board will be viewed with suspicion by the judiciary. In addition, although the judiciary has not specifically referred to the concept yet, it is likely that the Ministry Guidelines' requirement that a defense be reasonable in relation to the threat posed will eventually factor into this evaluation. Poison pills that are entirely preclusive of hostile takeovers, perhaps by being combined with other measures, are likely to be viewed as impermissible, while those allowing a target board to have the time and leverage to negotiate for a higher bid will be more likely to receive approval.

Of course, American corporate lawyers reading the above assessment will undoubtedly recognize that Japan has borrowed some of its doctrine from Delaware jurisprudence. ${ }^{83}$ The concepts of maximizing shareholder value,

83. See Milhaupt, supra note 11, at 2195-97 (specifically discussing how the CVSG report, upon which the Ministry Guidelines were in part based, bears a striking resemblance to Delaware jurispru dence). 
relying on disinterested parties to make the redemption decision, and structuring a pill so that it is reasonable in relation to the threat posed are all cornerstones of Delaware's takeover defense review. ${ }^{84}$ However, in Japan's adaptation of Delaware jurisprudence to suit its own circumstances, it has established a subtle, yet crucial difference from Delaware: while Delaware courts apply their takeover review standards at the stage when a challenge is made to the directors' decision not to terminate a particular defense measure,$^{85}$ Japan is moving toward application of similar standards at a stage when directors are merely attempting to adopt a defense. In other words, Delaware review of takeover defenses can be characterized as ex post ${ }^{86}$ while Japanese courts are setting precedents for an ex ante analysis of poison pills and other defenses.

Although the decisions made by the Japanese judiciary thus far in Livedoor and Nireco were clearly correct based on obvious flaws in the respective defenses, one must wonder whether the application of Delaware standards from an ex ante position might create a hurdle that is simply too high for even well-intentioned companies to overcome when their poison pills are challenged. Since "Delaware takeover jurisprudence, consisting of loosely defined, fact-intensive standards, is indeterminate even on home soil," ${ }^{87}$ this outcome appears very possible where a judiciary attempts to establish an ex ante review using standards similar to Delaware. This is simply because at the stage of adoption, there is an utter lack of facts and evidence for courts to examine in coming to a decision. Rather, to a much greater extent than the Delaware judiciary faces in its ex post review, the Japanese courts and the parties to the lawsuit will essentially have to guess as to what the directors

84. See, e.g., Unocal Corp. v. Mesa Petroleum Co., 493 A.2d 946, 955 (Del. 1985) ("In the board's exercise of corporate power to forestall a takeover bid our analysis begins with the basic principle that corporate directors have a fiduciary duty to act in the best interests of the corporation's stockholders."); Moran v. Household Int'l, Inc., 500 A.2d 1346, 1356 (Del. 1985) ("[T]he directors must show that the defensive mechanism was 'reasonable in relation to the threat posed.' Moreover, that proof is materially enhanced, as we noted in Unocal, where, as here, a majority of the board favoring the proposal consisted of outside independent directors who have acted in accordance with the foregoing standards." (citation omitted)).

85. See Vlahakis, supra note 14, at 1331 (stating that "[ $\mathrm{t}]$ here is currently no doubt as to the legality of rights plans.... Therefore, almost all litigation concerning rights plans now focuses on whether or not a board should be required to redeem the rights in response to a particular bid.").

86. William B. Chandler III, Hostile M\&A and the Poison Pill in Japan: A Judicial Perspective, 2004 Colum. Bus. L. Rev. 45, 54 (stating that "in the Unocal decision, the Delaware Supreme Court . . . announced that such defensive actions would be reviewed under enhanced judicial scrutiny —an objective ex post review by the court to assess whether a board's use of a particular defensive measure was 'reasonable in relation to the threat posed."' (emphasis added)).

87. Milhaupt, supra note 11, at 2209. 
intend by the defense or whether it is designed to protect shareholder value. For example, if the Nireco case had to be decided without an obvious flaw in the technical structure of the pill, what would the court actually have based its decision upon? If the pill would have been struck down simply because the board did not relinquish every fiber of its power regarding the redemption decision, that is a harsh precedent that is frankly insulting to the directors whose duty it is to protect the company and its shareholders. If the decision would necessarily have depended on something else, perhaps a suspicion of the court that the particular directors would act in their own self-interest, then the Japanese courts may have stumbled across something that is not so much a legal evaluation as it is a forum for incredulity.

While the idea has been proffered that Japan selected features of Delaware jurisprudence not necessarily for their intellectual superiority to the alternatives but rather for their "elastic quality," whether the standards are so flexible that their application in an ex ante context can be effective. The goal in developing a doctrine to review takeover defenses should be to never allow tactics motivated by management selfinterest, to always allow tactics motivated by an effort to secure the best price for shareholders, and to carefully review tactics that are motivated by a claim that more time is needed to evaluate an offer so that self-interest is not the actual force at play. ${ }^{89}$ Since an ex ante application of Delaware standards involves considerable guesswork, it is questionable whether these goals can be met with Japan's doctrinal direction. Furthermore, ex ante review of poison pills may inherently be weighted towards rejection of the pill, since it makes establishing a threat more difficult than in Delaware ${ }^{90}$ and simply does not provide directors with the opportunity to demonstrate that they utilized a defensive measure for the company's benefit in actual practice. By forcing directors to justify their pill's characteristics at adoption rather than allowing them to show how a pill benefited shareholders upon the occurrence of a tender offer, Japan's jurisprudence may be viewed as something of a

88. Id. at 2213

89. Gilson, supra note 20, at 31 .

90. In fact, Delaware companies are free to adopt poison pills by board resolution without showing a specific threat of any kind. This is because Delaware recognizes three general theories of threats that arise in the takeover context: (1) opportunity loss, where a hostile offer might deprive target shareholders of the opportunity to select a superior alternative offer; (2) structural coercion, where the risk of disparate treatment of non-tendering shareholders might distort shareholder decision-making; and (3) substantive coercion, where the shareholders may mistakenly accept an underpriced offer because they do not believe management's assertion that the company's actual value is greater. See Unitrin, Inc. v. Am. Gen. Corp., 651 A.2d 1361, 1384-88 (Del. 1995). 
preemptive strike against poison pills. If poison pills are not given a reasonable opportunity to be adopted in spite of challenges by shareholders, then the issue of judicially separating pills that benefit shareholders from those that entrench management becomes moot.

A counterargument to this assessment is that it remains entirely possible for a Japanese company to adopt a poison pill or other defensive measure by receiving shareholders' approval at a general meeting. As mentioned, eight companies successfully gained the approval of their poison pills by shareholders in June 2005. However, it is interesting to note that several of these pills were structured such that, even if they had been adopted without shareholder approval, they would likely have passed muster under a judicial challenge. For example, the rights plans approved by the shareholders of Seino Transportation Co., Pentax Corp., and eAccess Ltd. all contained a mechanism to reflect the shareholders' will and avoided the risk of unforeseen damage to shareholders other than the hostile bidder. ${ }^{91}$ In the case of eAccess, it protected its shareholders by placing the redemption decision in the hands of the company's independent directors and by providing a sunset provision requiring that the plan be approved by shareholders every three years if it is to continue. ${ }^{92}$ In addition, eAccess utilized a trust arrangement to avoid the problem under the Commercial Code of ensuring that stock and stock acquisition rights are held together. ${ }^{93}$

This potential convergence between the characteristics of pills that are adopted by board resolution and those adopted via shareholder approval means that directors' aversion to relinquishing their duty of setting corporate policy perhaps cannot be avoided through either method of adoption. In addition, one should not assume that the eAccess type of arrangement would be palatable, or even possible, for most Japanese companies because about three-fourths of the companies still have board structures that do not include independent outside directors. ${ }^{94}$ For the majority of companies, the only methods available to satisfy considerations of shareholders' will and the prevention of arbitrary decisions might be to grant power over the redemption

91. Atsuhiko Jingu, Shihon Seisaku no Saikin no Doukou—Saikin no Baishuu Boueisaku no Doukou [The Recent Trends in Capital Policies-Recent Takeover Defense Trends] (Aug. 1, 2005), http://www.azsa.or.jp/b_info/ipo/200508/ipo_200508_01.html (in Japanese).

92. eAccess to adopt eAccess Rights Plan, May 12, 2005, at 1, available at http:// www.eaccess.net/press_img/2710_pdf.pdf.

93. Id. at 3. This ingenious arrangement has also been proposed by the firm of Mori Hamada \& Matsumoto. See Kawai, supra note 24, at 16-18. For more information on the problem of ensuring that stock and rights are held together, see supra note 65.

94. Milhaupt, supra note 11, at 2186-87. 
decision directly to shareholders or to complete outsiders. This clearly will not be acceptable to many Japanese directors, nor should it be. As a result, it seems possible that the current doctrine will lead to relatively limited usage of the poison pill in Japan as compared to the United States, whether gaining shareholder approval is plausible or not.

\section{Potential Repercussions of the Japanese Doctrine}

Among some commentators, Japan's "shareholder friendly"95 approach to the pill will undoubtedly be met with praise. Although even the most vocal critics of the poison pill in the United States will admit that it has more often worked to improve the target board's negotiating position for a higher price than it has to entrench self-interested management, this is of course a result of the pill being vigorously policed in the United States by independent directors, courts, and investors rather than the inherent design of the pill itself. ${ }^{96}$ Because it has been argued that the forces of independent directors and investors in Japan are comparatively weak, ${ }^{97}$ it will be seen as natural and laudable by some observers that Japanese courts have come down harshly on the pill to compensate for the dearth of other mitigating factors and to avoid the pill's potential detriments.

However, recent displays of shareholder activism and the composition of the current market in Japan cause one to hesitate in blindly accepting the position that investors cannot play an effective policing role for Japanese poison pills. Japanese investors have recently shown signs that they are indeed capable, as at the June 2005 shareholders' meetings they contributed to successful votes against three companies' attempts to increase the amount of authorized capital stock, and "several [Japanese] public retirement plan sponsors collectively managing over $\$ 1$ trillion in assets have recently established proxy voting guidelines that emphasize corporate governance considerations." ${ }^{\circ 8}$ Furthermore, as of March 31, 2005, foreign ownership of Japanese stocks was at a record 23.7 percent of publicly traded shares (worth

95. This was the phrase used by the Director of METI's Industrial Organization Division to describe the Ministry Guidelines during a 2005 interview. See Japan External Trade Organization, JETRO Spotlight Interview: Satoshi Kusakabe (2005), http://www.jetro.org/content/263. Clearly, the court decisions discussed in this Note have moved even closer to what is being perceived as a "shareholder friendly" doctrine.

96. Gilson, supra note 20 , at 33-40.

97. Id. at 41 .

98. Milhaupt, supra note 11, at 2185. 
a total of $\$ 840$ billion), ${ }^{99}$ and as of November 18,2005 , foreign investors had made net purchases of $\$ 78.9$ billion worth of Japanese shares during the 2005 calendar year. ${ }^{100}$ Much of this foreign purchasing is being done by the same institutional investors that effectively police corporate decision-making in the United States, such as CalPERS. ${ }^{101}$ The Nireco case itself demonstrates how a foreign plaintiff can successfully influence Japanese corporate governance, and more recently U.S.-based Liberty Square Asset Management took the activist lead against Asahi Broadcasting's proposal to protect itself by issuing new shares to its affiliated companies. ${ }^{102}$

The increasing strength of shareholders' voices in Japan, coupled with the likelihood that the number of companies including independent directors on their boards is expected to increase,$^{103}$ is perhaps further evidence that the doctrinal direction of the Japanese judiciary will prove to be too strict in limiting poison pills' ability to survive challenge. If Japanese companies struggle in defending themselves from takeovers in relation to this point, it is foreseeable that the Japanese Diet (legislature) might pass legislation that intervenes and makes poison pills and other takeover defenses easier to adopt for Japanese companies. This is especially possible because, despite the fact that the majority of recent hostile activity in Japan has been carried out by Japanese companies, there is an underlying fear of foreign takeovers that has resulted in a theme of nationalist protectionism in political and bureaucratic discussions of takeovers. ${ }^{104}$ For example, a storyline of the Livedoor saga was that in order to finance its NBS bid, Livedoor issued \$759 million of convertible bonds to Lehman Brothers, the U.S. investment bank. ${ }^{105}$ As fear arose that Lehman Brothers would indirectly gain control of NBS and Fuji TV after converting its bonds to Livedoor stock, "Lehman was forced to issue a statement saying it had no intention of controlling Livedoor or entering the Japanese media industry."106 More recently, with regard to Japan's new

99. John Brinsley, Poison Pill Defenses Take Spotlight in Japan, Int'L Herald TriB., June 21, 2005, http://iht.com/articles/2005/06/20/bloomberg/sxtakeover.php.

100. David Turner, Foreigners Buy into Japan's Recovery, Fin. Times, Nov. 28, 2005, at 1.

101. Milhaupt, supra note 11, at 2184 .

102. David Ibison, Asahi Accused of Shareholder Rights Abuses, Fin. Times, Nov. 30, 2005, at 28.

103. Milhaupt, supra note 11, at 2186-87.

104. It should be noted that this protectionist view is certainly not unique to Japan. For example, in 2005 the United States Congress effectively blocked a Chinese company's attempt to take over energy company Unocal. See Stephanie Kirchgaessner, 'Congressional Angst' Scuppers Chinese Bid, Fin. Times, Aug. 3, 2005, at 22. at 29.

105. Michiyo Nakamoto, Livedoor Seeks Court Injunction to Block NBS, Fin. Times, Feb. 25, 2005,

106. Michiyo Nakamoto, Livedoor Bid Puts Focus on MPOs, Fin. Times, Mar. 2, 2005, at 30. 
Company Law that is to take effect in April 2006, MOJ began considering a potential change that would have completely reversed the government's proposal of making all-stock mergers possible and thus encouraging foreign acquisition activity in Japan (a proposal that was already set to be delayed from its original initiation date until 2007). ${ }^{107}$ Specifically, the new rules would have forced a foreign company conducting a share-for-share exchange to secure a "super extraordinary resolution" from the target group's shareholders (considered to be nearly impossible) and to obtain a secondary listing in Japan. ${ }^{108}$ Although MOJ postponed the change after being warned by METI that the proposal was not consistent with the nation's goals for foreign direct investment, it remains possible that the restrictions will eventually take effect. ${ }^{109}$ Since share-for-share transactions are typically friendly, it is not unthinkable that even more severe regulations might sometime be proposed for the purpose of preventing hostile takeovers. One such regulation might include an easing of the requirements for Japanese companies to adopt poison pills.

Ironically, it was the predecessor organization of METI (coauthor of the Guidelines discussed earlier), the Ministry of International Trade and Industry (MITI), that was instrumental in the proliferation of cross-shareholding relationships in the 1970s that long served to protect companies from takeovers. For example, it is well known that MITI Minister Kiichi Miyazawa played a direct role in directing and facilitating the establishment of crossshareholdings when General Motors announced in 1969 that it was considering a large purchase of Isuzu Motors. ${ }^{110}$ The result was that General Motors was only permitted to buy thirty-five percent of the company, and only so long as the remainder of Isuzu shares was held by stable entities. ${ }^{111}$ While the modern-day METI certainly appears more open to takeovers than its predecessor, another ministry or even politicians themselves may initiate an amendment to the Commercial Code to counteract the high hurdles that have been foreshadowed for challenged poison pills thus far by the Japanese judiciary. ${ }^{112}$

107. David Ibison, Tokyo Merger Proposal 'Protectionist', Fin. Times, Nov. 22, 2005, at 34.

108. Id.

109. David Ibison, Tokyo Backs Down on Takeover Plans, Fin. TimEs, Dec. 2, 2005, at 29.

110. MiYASHITA \& RUSSELL, supra note 7, at 67.

111. Id.

112. In the wake of the Nireco decision, a member of the ruling Liberal Democratic Party was quoted as saying "[j] udges don't know what exactly is going on at businesses. You can never be sure how far you can trust their judgment." Poison Pill Guides Fail to Quell Anxiety, The Asahi Shimbun, June 24, 2005, http://www.asahi.com/english/Herald-asahi/TKY200506240155.html (on file with the author). While 
An even greater irony is that, without some intervention that makes poison pills and other defenses easier to successfully adopt in Japan, several factors seem to increase the likelihood that Japanese companies might return to the practice of stable cross-shareholdings in order to protect themselves from hostile takeovers. Some activity to this end has already been reported, particularly in the oil and steel industries. ${ }^{113}$ (Although this activity cannot be specifically identified as a response to poison pill jurisprudence, and in fact probably is not, it at least demonstrates that a return to cross-shareholding is not unthinkable in Japan.) In recalling that the main reason crossshareholdings unwound was the poor performance of the Japanese stock market, one must now consider that Japanese equities are on the rise, exemplified by the Nikkei 225 Average (a technology-weighted stock index) closing above 15,000 for the first time in five years during 2005 and the broader Topix index also reaching a five-year high. ${ }^{14}$ As a result, the accounting rules that require companies to recognize their shareholdings on a market value basis may be, at least for the time being, an incentive to purchase equities rather than sell. Furthermore, the Japanese banking industry, which previously played a significant role in cross-shareholding activity, is at its healthiest stage since the economic bubble and bad loan crisis of the 1990s. Mitsubishi UFJ Financial Group (MUFG), Mizuho, and Sumitomo Mitsui Financial Group (SMFG), the nation's top three banks, all reported dramatically improved profits and profit forecasts in $2005 .{ }^{115}$

politicians typically do not initiate amendments, in 1997 they acted to liberalize Japan's stock option regime through a Commercial Code amendment. See Milhaupt, supra note 11, at 2191. It is also interesting to note signs that MOJ may have been a reluctant partner of METI in the issuance of the Ministry Guidelines. MOJ was not only the ministry that recently took the lead in the reversal of positions regarding all-stock mergers before METI's warning caused it to hesitate, but it also sharply disagreed with METI over whether independent outsiders should be able to make choices on behalf of a company prior to the issuance of the Guidelines. One MOJ official was quoted as stating that "[i]ndependent outside directors have no legal grounds. There isn’t any precedent showing they are legal." Poison Pill Guides Fail to Quell Anxiety, supra.

113. Jeannine Mitchell, The Year of the Poison Pill, IR MAG., Aug. 2005, http://www.irmag.com/ feature.asp?current=1\&articleID=4290 (reporting that "two of Japan's major oil wholesalers-Nippon Oil and Cosmo Oil- have bought more shares in each other, as have major steel companies Kobe Steel, Nippon Steel and Sumitomo Metal Industries"). at 44 .

114. Dave Shellock \& Steve Johnson, Yen Founders as Tokyo Stocks Rise, Fin. Times, Dec. 2, 2005,

115. See David Ibison, MUFG Bests Toyota's Top Profit Performance, Fin. Times, Nov. 25, 2005, at 24; David Ibison, SMFG Reports Jump in Profits, Fin. TImes, Nov. 23, 2005, at 30; David Ibison, Restructured Mizuho Raises Full-year Forecast, Fin. Times, Nov. 22, 2005, at 34. 
This is not to say that poison pills and cross-shareholdings are strict alternatives, ${ }^{116}$ but to the extent that limitations on poison pills and other advance defensive measures encourage Japanese companies to return to their cross-shareholding roots, the strictures that have been placed on the poison pill may be viewed as harmful. While Japan's post-war economic success makes it difficult to argue that cross-shareholdings are purely inhibitory of growth, today's environment of heightened global economic competition is not one in which many companies can afford to tie up valuable liquid resources simply for the sake of preventing takeovers. If the judiciary's limits on the poison pill, the adoption of which does not immediately impact a company's capital structure or financial flexibility, lead to an upswing in cross-shareholdings, then it can be said with some reassurance that the current doctrine has failed to support Japan's recent economic revival. While poison pills that are not effectively policed might be harmful to Japan's needed equilibration of assets, ${ }^{117}$ there is reason to believe that effective policing by shareholders is possible. On the other hand, cross-shareholding is almost certainly harmful to the equilibration process, as it ties up capital that could achieve greater returns elsewhere and, once it has risen to certain levels, may entirely prohibit the market for corporate control.

\section{CONCLUSION}

Because of the preliminary nature of poison pills in Japan, few things are entirely certain. Nevertheless, it would appear that in its effort to promote a shareholder-friendly standard to evaluate takeover defenses, the Japanese judiciary has undercut the attractiveness of adopting poison pills for Japanese companies because of the difficulty in overcoming shareholder challenges. In attempting to apply characteristics of Delaware takeover jurisprudence from an ex ante position, Japan has created a doctrine that seems inherently weighted towards rejection of the pill. Depending on whether the Diet passes legislation to counteract this standard, the precedents set in Livedoor and Nireco may or may not have lasting importance in Japan. For the time being, however, it is simply disappointing from an analytical perspective that

116. In fact, the Ministry Guidelines seem to allow cross-shareholdings to be used in conjunction with poison pills by stating that "[i]f there are shareholders who already own more than the specific percentage of stock [set as a trigger], such as $20 \%$, at the time that takeover defense measures are introduced, excluding such ownership from causing the defensive measure to be triggered does not constitute 'differential treatment among shareholders other than the acquiring person." See METI \& MOJ, supra note 21, at 17.

117. Gilson, supra note 20, at 29. 
Japanese companies are not being provided with greater discretion to adopt poison pills.

This is not only because the pill can satisfy the void left by the dissipation of cross-shareholdings, but also because it can never be said for certain whether Japan's infrastructure is developed enough to ameliorate the pill's potential abuses unless the pill is first given a broad opportunity to exist. In addition to the rise of shareholder activism, several other factors support the idea that Japan's infrastructure is indeed ready to support a pill that operates to increase shareholder wealth: directors now face a greater likelihood of liability for breaching their duties to shareholders than ever before as a result of an increased frequency of shareholder derivative litigation; ${ }^{118}$ the compensation of Japanese managers with equity-based instruments has recently grown and thus mitigates incentives for entrenchment upon receipt of a profitable takeover bid; ${ }^{119}$ and the potential for proxy fights to counteract directors' decisions not to redeem a poison pill is enhanced by the fact that staggered boards are not feasible under Japanese corporate law. ${ }^{120}$ Although merely an anecdotal observation, it is perhaps even more important to consider that "the American way of thinking - management for shareholders - is becoming widely accepted by Japanese managers. They are starting to try to enhance cash flow to shareholders and maximize share prices." 121

If there is indeed legislative intervention to make poison pills and other defensive measures easier to successfully adopt, it can only be hoped that it does not go too far in making the poison pill an instrument of preclusion. Since this would not be in the best interests of shareholders or the economy as a whole, the Japanese judiciary should consider a reformulation of its poison pill doctrine that will make it unnecessary for Japanese companies to lobby for intervening legislation. Specifically, consideration should be given to retracting the current focal points that seem to require identification of a specific cognizable threat and total relinquishment of the redemption decision by the board before a pill can successfully be adopted. Rather, in consideration of the general coercive effects takeover bids can have on shareholders, peacetime pills should be made feasible so long as reasonable shareholder protections are in place. Moreover, the province of directors as the policymakers of a corporation should be respected regarding the decision

118. See Milhaupt, supra note 11, at 2188.

119. Id. at $2187-88$.

120. Id. at 2202 .

121. Suzuki, supra note 10 , at 820 . 
of whether to redeem. ${ }^{122}$ In the U.S. experience, the poison pill has not acted as a preclusive defensive weapon but rather as a tool that improves the negotiating position of a target company's board and allows the company to carry out its business without the constant fear of an abrupt and disruptive takeover attempt. Japan's goal for the poison pill should be to achieve the same result and, given the nation's improved infrastructure for the policing of corporate governance, this goal seems attainable.

Regardless of how the poison pill doctrine develops, there is little question that Japanese companies will seek to defend themselves from takeovers in some form. A survey in early 2005 showed that managers of seventy percent of large Japanese companies were concerned about the threat of hostile takeovers, ${ }^{123}$ and in consideration of the implications of the Livedoor and Nireco decisions, the percentage may have increased since. As demonstrated by the defensive activities of NBS upon Livedoor's unsolicited purchase of shares, Japanese companies can turn to a variety of measures other than the poison pill to protect themselves. Indeed, the modern precedents for potential defenses involving crown jewels, increased dividends, white knights, and "borrowed" equity have already been established, and this Note points to the possibility of a reversion to cross-shareholdings in the future as well. Two general observations can be made about these alternative defenses - none of them is necessarily more effective than the poison pill in improving a target board's negotiating position, and all of them have the potential to be more economically disruptive than the adoption of the pill. On this basis alone, powerful motivations exist for the Japanese judiciary to rethink its current doctrinal approach as further challenges to poison pills are raised.

122. Giving directors considerable, if not complete, authority over the redemption decision does not necessarily harm shareholders because if the directors decide not to redeem a pill arbitrarily, they face the strong prospect of being sued. In a talk given by Professor Curtis Milhaupt of Columbia University in July 2005 that was moderated by the Research Institute of Economy, Trade, and Industry, he commented that "[w] hat is not well understood [in Japan] is that under Delaware law, even if a company has a pill in place they must re-evaluate the fairness of the pill in place in the face of a bid. That is often lost in the debate in Japan ...." Curtis Milhaupt, Is the Poison Pill Good for Japan?: A Preliminary Analysis of the New Takeover Guidelines (July 28, 2005), http://www.rieti.go.jp/en/events/bbl/05072801.html. Based on the current doctrinal direction, this fact may also be lost, or perhaps intentionally unconsidered, by the Japanese courts.

123. Milhaupt, supra note 11, at 2183. 